\title{
Pemberdayaan Kelompok Tani Rumput Laut dan Peternak Sapi di Kecamatan Suppa Kabupaten Pinrang
}

\author{
Andi Puspa Sari Idris ${ }^{1}$, Subariyanto ${ }^{2}$ \\ ${ }^{1}$ Politeknik Pertanian Negeri Pangkep \\ ${ }^{2}$ Universitas Negeri Makassar
}

\begin{abstract}
The purpose of this study was to train and guide people of Suppa village in Pinrang regency in cultivate Eucheuma Cottonii seaweed, processing seaweed waste and making simple biogas. The problem was the participants were not understand the process of cultivating the seaweed, processing seaweed waste to become other products, and processing cow manure to become biogas. Method used in this study was training by showing examples of implementation and mentoring process. The result of this study showed that the farmers of Eucheuma Cottonii seaweed able to do seaweed cultivation, do marketing and business management properly, and the fisherwomen able to process seaweed waste into processed products in the form of seaweed jelly and cattle farmers can utilize their cow manure into biogas.
\end{abstract}

Keywords: fisherwomen, empowerment, community, seaweed farmers, cattle breeders

\section{PENDAhuluan}

Desa Suppa merupakan salah satu desa yang terletak di Kabupaten Pinrang Sulawesi Selatan. Desa ini terkenal sebagai daerah perikanan di Sulawesi Selatan. Desa Suppa sebelumnya terkenal sebagai penghasil utama udang windu beberapa waktu lalu. Namun dengan kegagalan budidaya udang karena penyakit, maka sebagian masyarakat melakukan usaha budidaya rumput laut.

Usaha rumput laut juga telah berkembang di daerah ini, yang dikelola berdasarkan kebiasaan yang ada. Oleh karena itu, usaha ini perlu dikembangkan dalam rangka peningkatan produksi dan pendapatan masyarakat.

Disamping itu, ibu-ibu rumah tangga nelayan yang dalam kegiatan sehari-hari hanya ikut membantu suaminya dalam melakukan budidaya rumput laut, seperti membantu mengikat rumput laut pada saat akan melakukan penebaran benih atau membantu suami dalam hal panen dan pengeringan rumput laut. Kegiatan ini sifatnya temporer sehingga ibu-ibu nelayan memiliki waktu yang terbuang, yang mana jika waktu ini dimanfaatkan semaksimal mungkin, maka akan memberikan pekerjaan tambahan dan peningkatan penghasilan rumah tangga. Kegiatan yang dimaksud adalah, usaha pengolahan rumput laut menjadi berbagai produk olahan rumput laut.

Desa Suppa juga banyak terdapat ternak sapi yang dimiliki warga. Ternak- ternak sapi tersebut dibiarkan berkeliaran sehingga dapat mengganggu tanaman warga lain atau mengganggu lalu lintas karena tidak sedikit sapi-sapi tersebut masuk dalam kebun milik warga lain yang dapat menimbulkan komplik diantara mereka.

Sapi-sapi tersebut juga dapat menimbulkan kecelakaan karena sering masuk ke jalan raya dan tertabrak oleh kendaraan warga sekitar. Padahal, dalam pemeliharaan sapi ini, jika dikelola secara baik, maka akan menghasilkan produk sampingan seperti biogas.

\section{METODE PELAKSANAAN}

Sebelum dilakukan pelatihan terhadap mitra, maka terlebih dahulu dilakukan identifikasi permasalahan mitra, dan berdasarkan analisis tersebut maka ditemukan permasalahan masyarakat yang diberi nama Mitra 1 ini yaitu belum dikembangkannya teknologi budidaya rumput laut dengan baik, termasuk penentuan lokasi budidaya, teknik pemilihan benih, teknik budidaya, panen dan pasca panen, pengemasan sampai pemasaran dan manajemen usaha. 
Mitra 2 merupakan istri dari petani rumput laut tersebut juga ikut membantu suami, seperti pengikatan bibit rumput laut sebelum ditebar, dan pengeringan rumput laut. Padahal, terdapat suatu usaha yang dapat menambah penghasilan keluarga yaitu pengolahan berbagai olahan rumput laut menjadi berbagai produk, seperti nugget rumput laut. Masalahnya adalah mereka belum terampil dalam melakukan diversifikasi pengolahan rumput laut tersebut.

Pada Mitra 3 yang merupakan peternak sapi adalah mereka yang memiliki ternak sapi namun kotoran sapi yang dimiliki belum dimanfaatkan dengan baik. Padahal, kotoran sapi ini dapat dimanfaatkan untuk berbagai keperluan, seperti kotoran sapi dapat dirubah menjadi gas untuk memasak di dapur. Masalahnya adalah mereka belum terampil untuk membuat biogas dari kotoran sapi.

Dalam mengatasi permasalahan Mitra 1 terkait dengan permasalahan dalam produksi rumput laut, Mitra 2 yang terkait dengan pengolahan limbah rumput laut menjadi produk serta Mitra 3 berupa pengolahan kotoran sapi menjadi biogas, maka dilakukan kegiatan berupa penyuluhan/pelatihan dan pendampingan.

Setelah ditemukan dan ditentukan masalah mitra, maka langkah selanjutnya adalah mencari solusi penyelesaian masalah. Solusi yang ditawarkan ke Mitra 1 ini adalah kegiatan pelatihan dan pendamping tentang teknik budidaya rumput laut yang baik, termasuk dalam penentuan lokasi, pemilihan bibit, teknik budidaya sistem longline, cara panen dan pasca panen yang baik, pengemasan sampai kepada manajemen usaha. Solusi yang ditawarkan adalah pelatihan dan pendampingan pembuatan berbagai olahan rumput laut seperti kerupuk, manisan, dodol, nugget dan berbagai olahan rumput laut lainnya. Dalam kegiatan ini juga akan dilatihkan tentang cara pengemasan dan pemasaran serta manajemen usaha yang baik, serta mereka akan dilatih dan diberi pendampingan tentang teknik pembuatan gas dari kotoran sapi untuk keperluan rumah tangga bagi Mitra 3. Pada akhir kegiatan akan dilakukan evaluasi terhadap seluruh kegiatan yang dilakukan terhadap ketiga mitra. Untuk jelasnya gambaran iptek yang akan dilaksanakan pada mitra seperti pada Gambar 1.

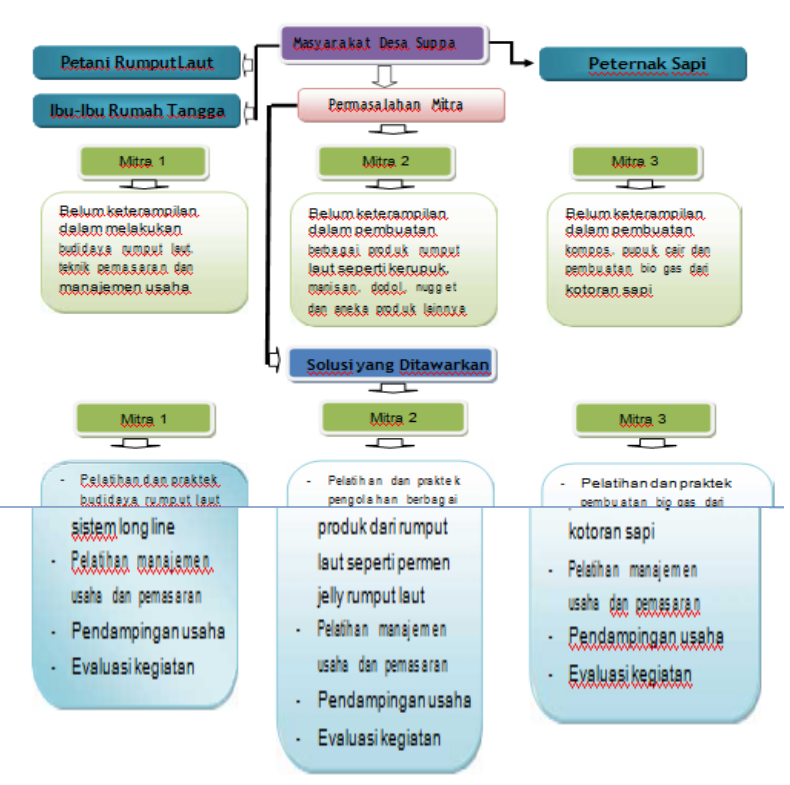

Gambar 1. Bagan solusi yang dilaksanakan pada mitra

\section{HASIL DAN PEMBAHASAN}

\section{A. Mitra 1}

Pada Mitra 1, mereka dilatih tentang cara penentuan lokasi budidaya, karena kesalahan dalam penentuan lokasi akan berpengaruh terhadap kualitas air yang sesuai kebutuhan rumput laut. Demikian pula dengan penentuan bibit, karena kesalahan dalam penentuan bibit akan berpengaruh terhadap pertumbuhan dan produksi rumput laut. Mitra 1 juga dilatih budidaya rumput laut Eucheuma cottoni sistem longline, yaitu budidaya rumput laut dengan menggunakan tali sepanjang 50-100 meter yang pada kedua ujungnya diberi jangkar dan pelampung besar. Kelebihan metode ini adalah dapat memberikan pengaruh kepada kualitas rumput laut dimana rumput laut tersebut akan memiliki banyak nutrisi sehingga pertumbuhannya akan lebih baik. Selain itu, metode ini juga akan sangat mempengaruhi hasil panen. Mitra 1 juga dilatih dalam memasarkan produk dan manajemen usaha karean kesalahan dalam dua faktor ini akan mengakibatkan kerugian bagi mitra itu sendiri. Kegiatan pelatihan pada Mitra 1 seperti pada Gambar 2. 


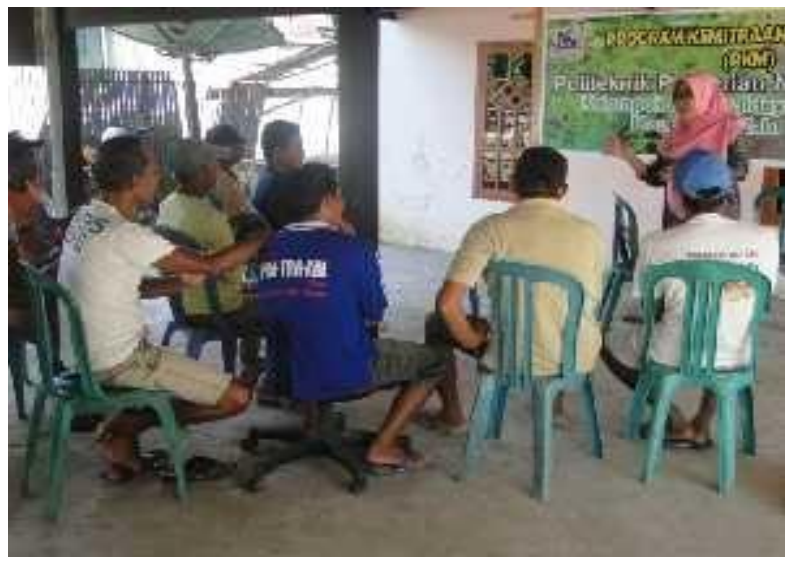

Gambar 2. Proses pelatihan bagi Mitra 1, pembudidaya rumput laut.

\section{B. Mitra 2}

Mitra 2 adalah ibu-ibu rumah tangga. Pada mitra ini dilatih membuat olahan limbah rumput laut menjadi permen jelly rumput laut. Pembuatan permen jelly rumput nilai tambah rumput laut dan diversifikasi olahan rumput laut. Proses pembuatan permen jelly rumput laut seperti pada Gambar 3.

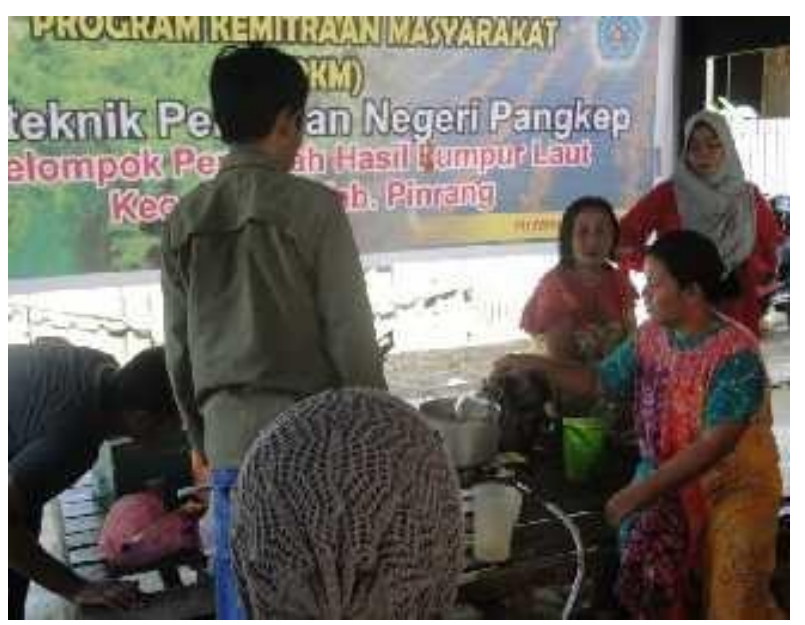

Gambar 3. Proses pembuatan permen jelly rumput laut

Hasil permen jelly rumput laut yang dilakukan Mitra 2 selanjutnya didinginkan dan dikemas dengan menggunakan kemasan plastik, seperti pada Gambar 4.

\section{Mitra 3}

Mitra 3 adalah kelompok peternak sapi yang ada di lokasi program. Mitra 3 ini dilatih dalam pembuatan biogas dari kotoran sapi seperti pada Gambar 5. Kelebihan pembuatan biogas dari kotoran sapi adalah ampasnya dapat dijadikan bahan pembuatan pupuk kompos.
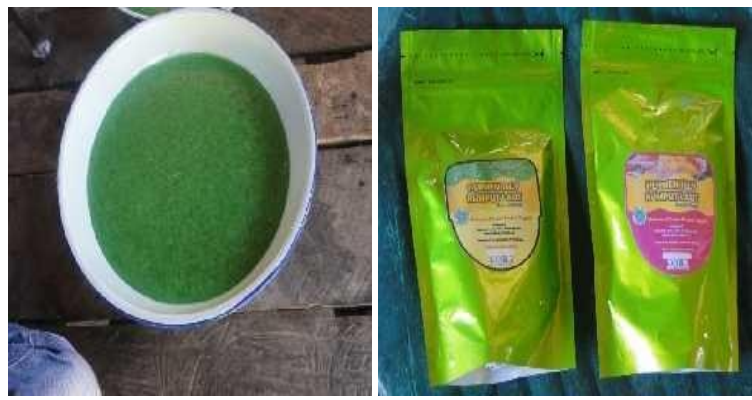

Gambar 4. Hasil pembuatan permen jelly rumput laut

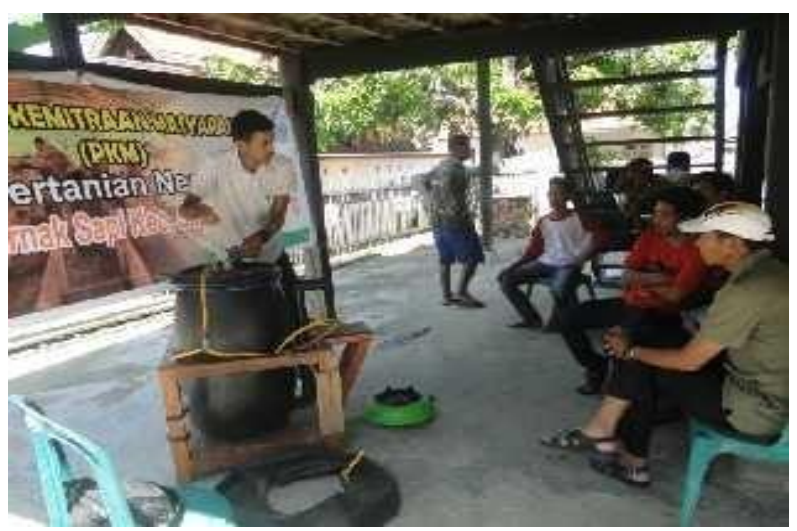

Gambar 5. Pemberian materi pembuatan biogas dari kotoran sapi

\section{KESIMPULAN}

Berdasarkan kegiatan ini, maka mitra 1 sudah dapat melakukan proses budidaya rumput laut Eucheuma cottoni dengan baik, Mitra 2 dapat memanfaatkan limbah rumput laut menjadi olahan rumput laut seperti permen jelly serta pada Mitra 3 sudah dapat melakukan pemanfaatan kotoran sapi menjadi biogas.

\section{UCAPAN TERIMA KASIH}

Ucapan terima kasih kepada Direktorat Jenderal Pendidikan tinggi yang telah memberikan Hibah Program Kemitraan Masyarakat tahun 2018 ini. Selanjutnya ucapan terima kasih kami sampaikan kepada Rektor Universitas Negeri Makassar dan Pemerintah Kabupaten Pinrang atas kepercayaan yang diberikan kepada kami dalam melaksanakan program tersebut. 